\title{
Why Technoscience Cannot Reproduce Human Desire According to Lacanian Thomism
}

\author{
Graham McAleer, Christopher M. Wojtulewicz
}

ABSTRACT Being born into a family structure-being born of a mother-is key to being human. It is, for Jacques Lacan, essential to the formation of human desire. It is also part of the structure of analogy in the Thomistic thought of Erich Przywara. AI may well increase exponentially in sophistication, and even achieve humanlike qualities; but it will only ever form an imaginary mirroring of genuine human persons-an imitation that is in fact morbid and dehumanising. Taking Lacan and Przywara at a point of convergence on this topic offers important insight into human exceptionalism.

KEYwords desire; Lacan, Jacques; matter; motherhood; philosophical theology; Przywara, Erich; psychoanalysis; technoscience

\footnotetext{
\& Graham McAleer, Department of Philosophy, Loyola University Maryland, 4501 N. Charles Street, Baltimore, MD 21210, USA [ gmcaleer@loyola.edu (D) 0000-0001-9562-2242

\& Christopher M. Wojtulewicz, Free Research Associate KU Leuven, Sint-Michielsstraat 4- box 3101, 3000 Leuven, Belgium

(D) $0000-0003-3687-153 \mathrm{X}$

(c) (i) ForUm PhiLOSOPHICUM 24 (2019) no. 2, 279-300 ISSN 1426-1898 E-ISSN 2353-7043

Subm. 19 August 2019 Acc. 21 October 2019 DOI:10.35765/forphil.2019.2402.13
} 
The robot revolution is coming; about this we have no doubt. There is every reason to believe that within a decade, robots will be flitting about amongst us. There are even suggestions that within two decades "35\% of current jobs in the UK could become automated." Early trials in supermarkets and hotels show we will welcome them into our lives the way we do our dishwashers. ${ }^{2}$ Is the probable nonchalant acceptance of AI a crisis for Christianity? AI dressed up in the ideology of transhumanism will certainly be a challenge for the Church, comparable to, and really, just another iteration of, the challenge posed by atheistic humanism. ${ }^{3}$ Indeed, it is a challenge stretching back to the disenchantment wrought by Early Modern philosophy. ${ }^{4}$ Will AI be a moment of vertigo for Christians? Will it scramble our bearings utterly? We do not think so. There is an understandable fear that AI might sideline a Christian view of the human person, but we expect it to reaffirm the importance of motherhood and family.

Christian theology does assume human exceptionalism. No other animal has been promised to behold God face to face. The Incarnation ratifies the witness of Hebrew Scripture that we hold a unique place in God's life. Human exceptionalism has been under pressure at least since Hume, and more recently with primate studies. ${ }^{5} \mathrm{AI}$ offers a new pressure from another direction, the idea of another kind of rational life extraordinarily like ours. There is evidence that self-taught computers learn just like humans, first organizing the world by shape. ${ }^{6}$ Christian anthropology is caught in a pincer movement, and humankind's greatest imaginable privilege appears ready to topple: Why should arbitrary biological data processors warrant the visio beatifica? Disenchantment complete, Christianity will collapse under the weight of its own pretention. To the transhumanist, Christianity

1. Parliament, House of Lords, "Make or Break-The UK's Digital Future," Report of Session 2014-5 (London: Select Committee on Digital Skills, 2015), 6, https://publications.parliament. uk/pa/ld201415/ldselect/lddigital/111/111.pdf.

2. Rich DeMuro, "Walmart Robots Working Store Aisles, Checking Stock-YouTube," accessed August 3, 2019, https://www.youtube.com/watch?v=KRJV1SPYpIE.

3. Henri de Lubac, The Drama of Atheist Humanism, trans. Edith M. Riley, Anne Englund Nash and Mark Sebanc (San Francisco, CA: Ignatius Press, 1995).

4. Jason A. Josephson-Storm, The Myth of Disenchantment: Magic, Modernity, and the Birth of the Human Sciences (Chicago, IL and London: University of Chicago Press, 2017).

5. Take, as one of many examples, the famous and moving story of Kanzi-see Sue SavageRumbaugh and Roger Lewin, Kanzi: The Ape at the Brink of the Human Mind (New York, NY: John Wiley \& Sons, 1994).

6. Christopher Mims, "Career of the Future: Robot Psychologist," Wall Street fournal, 9 July 2017, sec. Tech, https://www.wsj.com/articles/career-of-the-future-robot-psychologist-1499605203 (Paywall). 
makes an incredible claim: a neither especially agile animal, nor one adroit at thinking, is the beloved object of a God who sacrifices himself uniquely for an unremarkable creature. The glee of the technological materialists is palpable, but have they really understood Christian anthropology?

Why was Christ born of a woman? Christian personalism has never been the claim that we are pure reason but always rather that we are embodied, desiring, rational agents. All of us have a unique origin as materia signata (the principle of individuation). This Thomistic phrase picks out not only each singular's unrepeatable co-ordinates in space and time but, in the case of the human being, our births, our relationship not merely to the vulnerability of materia (matter), but also the vulnerability of mater (mother). Christ was born of a woman, fully God, but also fully human, and thus subject to all that it means to be born within the human community.

AI has physical coordinates: whether code or robot, AI takes identity from materia signata and shares in the vulnerabilities posed to everything with historical placedness. ${ }^{7}$ Though some technologists ${ }^{8}$ glibly speak of our becoming immortal if we can but be thoroughly synthesized with data, data cannot escape the metaphysical problem of materia prima-what relationship, if any, would such data have to materiality? This is a purely formal metaphysical problem: perhaps only Leibniz has found a way to circumvent this metaphysical doom, but as he pointed out in 1714, no computer is a monad (The Monadology, paragraph 17). But more striking is the vulnerability AI cannot share with us: mater. There are many science fiction thought experiments in which AI becomes self-conscious. ${ }^{9}$ That may well come to pass. Even if it does, AI will not then be like us, but something

7. An illustration of this is the way investors think of Google. To you and me it seems so very ethereal and digital but to investors it is in fact an energy company. Its energy use is the same as the city of San Francisco. Its data processors are housed close to hydroelectric reservoirs and dams. Its risk profile for investors is the same as for any other energy company. See Andy Kessler, “Will Bitcoin Save Us from Google?”, 16July 2018, https://www.andykessler. com/andy_kessler/2018/07/wsj-.html; see also Alejandra Borunda, "The Internet Is Drowning," Science \& Innovation, 16 July 2018, https://www.nationalgeographic.com/science/2018/07/ news-internet-underwater-sea-level-rise/.

8. Pope Francis has drawn new attention to technoscience, see Pope Francis "Laudato Si': On Care for Our Common Home," Encyclical Letter, 24 May 2015, §102-5, https://w2.vatican. $\mathrm{va} /$ content/francesco/en/encyclicals/documents/papa-francesco_20150524_enciclica-laudatosi.html). We acknowledge that some interested in AI might view it as a value neutral tool, a useful mechanism to amplify human life. With Francis, however, we think technoscience an ethos, a spirit of valuation that aims to reevaluate the significance of being human. Historically, this has not always been a positive valuation of human life. For this reason, throughout we use AI and transhumanism interchangeably.

9. See the potent moral theological reflection of the film: Alex Garland, Ex Machina, 2014. 
more like artificial angels. Angels are motherless. AI is motherless. We are not. Christ was born of a woman-fully human-so that humanity might be redeemed in Him.

No matter the future intimacies we might have with $\mathrm{AI}-$ as caregivers, surgeons, cooks, spouses-AI has the form of technoscience. Even if we expect AI to machine biological systems-micro bots inside our DNA, say-AI will always be industrial. It will be "birthed" by engineers and accountants, not mothers. The current business of $\mathrm{AI}$ is industrialism, but even if that were to change, even if corporations took pity on their property and allowed self-conscious AI freedom instead of slavery, it would not change the fact that AI has an origin story completely unlike that of humans. As they will not have mothers, they will never be born immature and grow in the nexus of human interrelations. The myth (Georges Sorel) of AI is Promethean. It is to empower us (to make us cyborgs and supermen) or to supplant us (to fold us into data streams). ${ }^{10}$ It is on account of our origin in immaturity that Christ became incarnate: our wounded desires need the balm of seeing God face to face. Christ came to overcome what Jacques Lacan calls our primal dereliction. As Erich Przywara would put it: the "consortium Dei as a consortium Dei a Deo derelicti." 11 The dereliction of an algorithm is hardly the concern of business plans concerning AI. God is the face of mother made whole, therewith, us made whole. Przywara again: "The imago Dei, in the full sense of this term, is the human being in the symbol of the 'crucified' and the "mother of seven sorrows." 12 What are the precise contours of the constellation-immaturity, desire, and mother-and its theological importance?

\section{THEsIS}

We look to a philosophical-theological questioning of any materialist worldview that directs progress in $\mathrm{AI} /$ transhumanism. Not through an appeal to an irrefutable philosophical challenge to such a worldview, but to the shape of human life and thought as suggesting the real limitations of technoscience.

We do not ask whether God could give the lumen gloriae to an AI that became self-aware, learnt of God, and sincerely sought God. ${ }^{13}$ Our claim is

10. Yuval Harari, Homo Deus (London: Vintage, 2017).

11. Erich Przywara, Analogia Entis: Metaphysics: Original Structure and Universal Rhythm, trans. John R. Betz and David Bentley Hart (Grand Rapids, MI: Wm. B. Eerdmans, 2014), 568.

12. Ibid., 569.

13. Is to become self-aware also to be able to love? The Lacanian Thomism we are proposing suggests not: self-awareness can be a red herring which directs away from the true reality of oneself and of an other-the encounter with an other being the foundation of real love. 
not that the privilege of beholding God face to face is an exclusive one; that God's generosity of love is metaphysically constrained. We do not dwell on this, but in such a case the gift of the lumen gloriae would likely make the AI an honorary angel. ${ }^{14}$ We take it that the principal source of Christian anxiety about the coming robot revolution is that it is deflationary. There is no doubt technologists see it this way: AI is the culmination of an Early Modern project to dislodge the foolish idea of the Christian God and to put humans finally in their place: we are not special, just arbitrary biological data processors, and not especially good ones.

In one light, transhumanism is the continuance of equality's attack upon privilege, discussed by Alexis de Tocqueville, ${ }^{15}$ and in another, related light, transhumanism is the latest articulation of humanitarianism's ressentiment, so brilliantly observed by Max Scheler. ${ }^{16}$ We prescind from these political theology approaches and assess rather whether the symmetry between $\mathrm{AI}$ and humanity assumed by technologists quadrates. First, working with Lacan, we show that the desire structure of being born of a mother is at least one important way in which we are distinguished from AI. Second, deploying Przywara's Thomism, we explain why our desire structure finds its proper place in Christ. Christian privilege does not collapse under the weight of its own pretention.

Oddly, of our two thinkers, it is surely Przywara who needs most introduction. It is fair to say that Lacan is highly admired in the most refined theoretical circles. The Polish-German Jesuit, Erich Przywara, is barely known even inside Catholic circles. His Analogia Entis (1932/1962) is a monumental and profound work of Thomism. To make our argument, we draw from it Przywara's account of Mary as veil of Christ and compare and contrast it with Lacan's treatment of a mother's love as veil of the phallus. In so doing, we show that the prospect of AI reproducing human desire is untenable.

14. Or, rather fascinatingly a pure nature graced. Now known in the Church as the de LubacCajetan debate, a long-standing question has been whether God could create a pure nature and then add grace to it. Post Vatican II, consensus has been with de Lubac, who argued that this duplex ordo idea made no sense. Does AI push the dial back to Cajetan? It does seem so.

15. See Gail Bossenga, The Politics of Privilege: Old Regime and Revolution in Lille (Cambridge: Cambridge University Press, 2002), 9-12.

16. Max Scheler, Ressentiment, trans. Lewis B. Coser and William W. Holdheim, New Ed., Marquette Studies, in Philosophy 4 (Milwaukee, WI: Marquette University Press, 1994); see also Jeanne Riou and Mary Gallagher, eds., Re-Thinking Ressentiment: On the Limits of Criticism and the Limits of Its Critics, Cultural and Media Studies (Berlin: De Gruyter, 2016), 8-14. 


\section{Desire Structure}

Even if AI becomes truly intelligent and self-aware, it will still be true that the desire structure of AI will be sui generis different from ours. It is on account of our desire structure that we are promised to meet face to face the creator Logos, born of a woman. Though there is a long-standing positive interaction between theology and psychoanalysis, especially in Belgium and the Netherlands, there is a common perception in the academy that the two are at loggerheads. Perhaps this is because Lacan has seemingly received an exclusive reception among intellectuals broadly on the Left, though, from the perspective of theory, it is not immediately obvious why this should be the case. ${ }^{17}$ In our opinion, Lacan definitively shows the prominence desire holds in subjectivity. Catholic personalism has never been reduced to the simple idea that the defining feature of humanity is rationality, and certainly not in the narrow sense of our ability to ratiocinate. Ours, as Lacan and Aquinas point out, ${ }^{18}$ is a projective rationality, ordered about inclinations and desires, melded with the materia signata peculiar to us, born of mater.

Lacan frequently speaks of our desire in terms of algorithms and relationships between computers. These avenues complement his projective geometry; his claim that each of us has desire uniquely and inescapably born of a civilization made intimate to us through particularized family dynamics-what he calls, "the topology of the subject." ${ }^{19}$ On account of our lack of motor coordination at birth, our identity is not complete. This ties together the materiality of motor coordination with the immateriality of identity, and in consequence, our materia signata takes definitive shape with what Lacan calls the "phallus" (that which supplies for a lack). This shaping of our materia signata means concretely: a cradled period of gestation outside of the womb, oriented by the problem of love, its suffering, and the insatiable gravitation towards what is lacking in ourselves, and others, in order to supply for this lack (the phallus). This is not the stuff of technoscience: we live in a commercial civilization and the Apex machine is AI, its materia signata inescapably marked by industrialism (utility) and the business of bot production (replication).

17. Graham J. McAleer, "Jacques Lacan: Conservative Icon?”, Law \& Liberty, January 17, 2018, https://www.lawliberty.org/2018/01/17/jacques-lacan-conservative-icon/.

18. Graham J. McAleer, Ecstatic Morality and Sexual Politics: A Catholic and Antitotalitarian Theory of the Body, Moral Philosophy and Moral Theology Series 5 (New York, NY: Fordham University Press, 2005).

19. Jacques Lacan, "Position of the Unconscious," in Écrits: The First Complete Edition in English, trans. Bruce Fink (New York, NY: W.W. Norton, 1948), 709. 
Axiomatic to Lacanian psychoanalysis is the distinction between need and desire. Meaning is our fate-"the subject finds his signifying place"-and thus our appetitive natures only gain articulation in language, amidst signifers. ${ }^{20}$ There is no cry of a child, no expression of a need, that does not demand to be understood. How the cry is understood is relayed back to the child as his or her demand, shaping an emerging psychology. Demand is what gives voice to need, and in satisfying need, demonstrates to the individual that there is some other thing (unconditional love) which remains unsatisfied: what remains is the "unconditionality of the demand for love."21 Demand is a third component in Lacan's ontology of appetite. Whilst attending to and satisfying the child's hunger with her breast, the mother is nevertheless poised to withdraw and leave the child's presence-whether for work, or any other practicality, on the one hand, or in simple virtue of the manifold manifestations of desires, preoccupying thoughts, and fantasies for other things, beyond the child. Demand is thus never ultimately adequate to the child because it is itself structured by phallic desire-a sort of distraction or deferment, curtailing the love offered the child in its need. Given the distraction, what is offered the child is desire, an unhappy remainder bridging the gap between the demand offered and the unrequited love.

How the cry (demand) is understood by the mother is determined by the phallus; that is, the mother's own relationship to love, male desire, sexual difference, and a whole host of meanings available in the civilization; what Lacan calls the symbolic, language in all its non-finite iterations.$^{22}$ Lacan: "it is thereby that what emerges in the subject's unconscious is the Other's desire, that is, [a desire for] the phallus that was desired by the Mother." ${ }^{23}$

The immersion of appetite in language is a "double play." The child's needs slip into a vast playfulness of metonymy and metaphor ${ }^{24}$ that is, those needs are combined with other expressed appetites, symbols, and discourses, and thus the child's needs immediately and irresistibly mutate and are substituted, becoming desire. We have a narrow, fixed set of needswe do have a nature-but our "signifying place," our materia signata, our

20. Ibid., 708.

21. Jacques Lacan, “The Signification of the Phallus," in Ecrits: The First Complete Edition in English, trans. Bruce Fink (New York, NY: W.W. Norton, 1948), 580.

22. Jacques Lacan, "In Memory of Ernest Jones: On His Theory of Symbolism," in Écrits: The First Complete Edition in English, trans. Bruce Fink (New York, NY: W.W. Norton, 2006), 599.

23. Jacques Lacan, "Guiding Remarks for a Convention on Female Sexuality," in Ecrits: The First Complete Edition in English, trans. Bruce Fink (New York NY: W.W. Norton, 2006), 617.

24. Lacan, "Signification of the Phallus," 581; see also Lacan, "In Memory of Ernest Jones," $597 f$. 
desire, is anything but narrow and fixed. Indeed, desire cascades: it is as non-finite and rococo as language. ${ }^{25}$ Our desire is returned to us from the Other by "the radical defile of speech." ${ }^{26}$ This fact necessarily puts each of us at a distance from ourselves, what Lacan calls fragmentation ${ }^{27}$-the ubiquity and pluriformity of that early fear we felt when we looked into the mirror and saw a glimpse of our future self as complete, whole, and unified; the fear that should this masked specular image be dethroned, fragmentation would ensue. ${ }^{28}$ All this is experienced by Lacan's barred subject, the castrated subject ${ }^{29}$-the subject who realises that, like our inchoately motor-coordinated infantile bodies, all desire is always fragmented and incomplete. In this respect, it would seem that technological advances can be seen to reflect an awareness of this incompleteness, in order to supply for it. Technoscience can thereby be seen to set itself up as the phallus to human incompleteness; but precisely on artificial (i.e. intentional, selfreflexive, and un-birthed) grounds.

Lacan thus argues that needs still register, certainly, but they are stimulated into fresh growth, "offshoots" or desires that, through the twists, tricks, and turns of the game structure of civilization-and more about that below-emerge in our psychology as "paradoxical, deviant, erratic, eccentric, and even scandalous." ${ }^{30}$ Our primary condition is alienated, our need transformed and foiled (castrated) by the chain of signification into which we are thrown, for we are "precipitated" by language ${ }^{31}$ Hence, we live as though something is amiss, our appetites and plans puzzlingly never quite coordinating (castration). Puzzlement at being amiss is thanks to the

25. We do not think this incompatible with Thomistic natural law rightly understood, please see Graham J. McAleer, Erich Przywara and Post-Modern Natural Law (Notre Dame, IN: University of Notre Dame Press, 2019).

26. Jacques Lacan, "Seminar on 'The Purloined Letter," in Écrits: The First Complete Edition in English, trans. Bruce Fink (New York NY: W.W. Norton, 2006), 40.

27. Lacan, "In Memory of Ernest Jones," 599. "Fragmentation" differs from the question of "splitting" (Spaltung), a term Lacan borrows from Freud, but which refers to the splitting of the subject-the fact that one cannot self-consciously know all that one knows. The split thus marks an essential difference from ego-psychology: we are permanently self-alienated, and unable to bring our whole self into conscious view.

28. Jacques Lacan, “Aggressiveness in Psychoanalysis," in Écrits: The First Complete Edition in English, trans. Bruce Fink (New York, NY: W.W. Norton, 2006), 85.

29. Lacan, "Signification of the Phallus," 581.

30. Ibid., 579 .

31. Jacques Lacan, "The Mirror Stage as Formative of the IFunction as Revealed in Psychoanalytic Experience," in Écrits: The First Complete Edition in English, trans. Bruce Fink (New York, NY: W.W. Norton, 2006), 76. 
unconscious $^{32}$ and appears to us in "dreams, slips, and witticisms,"33 and more sharply, and sometimes catastrophically, in madness.

"Need" splitting into "signification" is desire launched into the churning meaning of civilization. We are enchanted, for our desire pulses along the resources offered by civilization: people to meet, things to wear, rituals to perform, stories and myths to hear, gods and demons to venerate. Lacan is one of the great adversaries of disenchantment, showing conclusively that our desire has a vesture. We come into our identities amidst allurements. One of these is mater. This enchantment, as in fairy tales, is not straightforwardly loving and affirmational.

\section{MOTHER}

The phallus is the acceptable face of desire. It designates that which will satisfy the lack perceived in another. Children first take shape psychologically in the Mirror Stage. A child's fascination in front of a mirror is the self's "original dereliction." ${ }^{34}$ Apes and chimpanzees do not experience this enchantment. For the infant, the imago is both a jubilant and bleak experience. Gesturing, the child mimics the image in the mirror, sees others interacting with it, falls in love with it, in fact, but also picks up on something eerie: the image is more pulled together and glamorous than the child. The infant experiences interiorly the motor difficulties of a still-maturing and incompetent body. For this reason, this experience of love (narcissism) is accompanied by jealousy (aggression). The goodness of the image is evident to the child from the praise parents give to it-the imago is viewed as an object, and provokes jealousy in the child, aware that the glamorized image is not quite a match for the chaos of the infant's fledgling body. ${ }^{35} \mathrm{But}$ it is the imago that is the ratified self, the acceptable self. The primary experience of each person is thus "the drama of primordial jealousy."36 Stemming from the Mirror Stage, this bipartition, this jealously and aggression, is a feature of a psychological system Lacan calls the imaginary.

Key to understanding Lacan's topology of the subject is the role of imitation. Here, the earliest emergence of the ego is found within an aggressive dynamic which recognises (and attempts to forcefully dominate) all

32. Lacan, "In Memory of Ernest Jones," 594.

33. Jacques Lacan, "On a Question Prior to Any Possible Treatment of Psychosis," in Écrits: The First Complete Edition in English (New York, NY: W.W. Norton, 2006), 459.

34. Lacan, "Aggressiveness in Psychoanalysis," 99.

35. Ibid., 92.

36. Lacan, "The Mirror Stage," 79. 
instances of other persons in whom we recognise a semblance of ourselves-we look around us and spot other instances of our imago. ${ }^{37} \mathrm{We}$ all know the essence of this aggressive moment when, perceiving faults in others that on some level we know we also possess, we bristle with irritation. Lacan calls this "the other (with a lowercase o) of the imaginary dyad." 38 The imaginary order thus deals in dyads, in duplications or mirror reflections, and not the interrelation between discrete objects (which Lacan calls, in contradistinction to the imaginary, the symbolic). The symbolic is composed of basic matrices $^{39}$-fecund but aggressive coordinates initially tied to the idea of the mother (mater)-which determine our world, our psyche's projective geometry: every child casts "out onto the world the disorder that constitutes his being." ${ }^{40}$

This essential human experience undergirding the imaginary order is, we suggest, itself a semblable of the glass ceiling of AI: it can imitate-it can recognise the imago-but it has no unconscious, it has no symbolic subjectivity. For Lacan therefore, pursuant to his rejection of ego-psychology, self-reflection or self-consciousness are inevitable aspects of human existence, but insufficient conditions to fully constitute it.

Motherless, the most that can be expected of a machine, no matter how sophisticated the AI, is to express a variant of the imaginary structure of dyadic imitation. This is not to say that AI is inconsequential. Lacan is again important here with his claim that the imaginary presents us with something peculiar and falsifying at its heart: a fictional narrative. For Lacan, ego-psychology is so problematic because it exacerbates and solidifies fictional narratives. It is precisely at the level of fictional self-narratives that Lacan raises the problem of "psychotechnics:" the idea that the very creation of machines by human beings is the beginning of the refashioning of the human self-image. We return to this theme in the conclusion but the idea is that all human creation is two-way; all human creation has the concomitant effect of recasting the idea of what it is to be human. Interestingly, Lacan's point here again precludes the idea of reproducing ${ }^{41}$ human

37. See Lacan, "Aggressiveness in Psychoanalysis."

38. Jacques Lacan, "Remarks on Daniel Lagache's Presentation: 'Psychoanalysis and Personality Structure,"' in Ecrits: The First Complete Edition in English, trans. Bruce Fink (New York, NY: W.W. Norton, 2006), 568.

39. Lacan, "Aggressiveness in Psychoanalysis," 85; Lacan, "The Mirror Stage," 76.

40. Lacan, "Aggressiveness in Psychoanalysis," 93.

41. We appreciate that not all AI inquiry seeks to literally reproduce human experience per se. It seems, nevertheless, to rely on a priori human characteristics, which are abstracted out in order to be replicated (and possibly surpassed) in machines. We challenge the fundamental 
desire in AI: the blueprint of human desire used to create AI desire slips between our fingers as soon as the project commences-the blueprint is changed by the project at hand. And this is why AI is artificial intelligence and cannot track the (fraught) fullness of human intelligence; its underlying structure is always going to be a resemblance, mirroring, or imitation of only an element of human mental life. This thrusts a new anthropology back onto human nature-as though aspects of human mental life can be compartmentalized or abstracted out in this way. In this sense, it matters not how sophisticated AI becomes-however convincingly autonomous as an intellectual "creature" it can appear to be, and however much it seems to creatively and autonomously deviate from its original programming. AI will always be psychologically thin.

To put this another way: Lacan allows us to think seriously about the unconscious dimension of AI. To understand what Lacan means by that, one has to let go of the idea that the unconscious is some subterranean seat of strong desires or drives (like the energy of the machine). ${ }^{42}$ Portrayals of future $\mathrm{AI}$ as an analogue to the human consider life (human or artificial) almost exclusively in conscious terms-and, what is more, only ever within the register of the imaginary. This is why, ultimately, it is the structure of human desire (symbolic) which is foreclosed in creating AI, preventing it from ever being reproduced in anything other than another human being. "The question as to whether [the machine] is human or not," Lacan says, "is obviously entirely settled-it isn't." ${ }^{43}$ The machine may well be constituted by logical notation - the "succession of little 0 s and $1 \mathrm{~s}$ " to be human cannot be isolated from the Lacanian symbolic.

AI can only ever offer a thin psychology because, disturbingly, the violence of the jealousy in the imaginary, really a self-laceration, is borrowed from the symbolic. Product of the mother's phallus, the specular self-"donned armor of an alienating identity" 45 -is in fact a mask; it is the "veiled face," ${ }^{46}$

philosophical-theological assumptions in the anthropology which undergirds this general view, and consider whether the human exceptionalism assumed by Christianity is vulnerable to AI development.

42. Jacques Lacan, The Seminar of facques Lacan. Book 2: The Ego in Freud's Theory and in the Technique of Psychoanalysis 1954-1955, ed. Jacques-Alain Miller, trans. Sylvana Tomaselli (Cambridge: Cambridge University Press, 1988), 75.

43. Ibid., 319

44. Ibid.

45. Lacan, "The Mirror Stage," 78.

46. Ibid., 77. 
a "seeming." ${ }^{\text {"77 }}$ It must be a mask, for otherwise the "self" is too shocking, riven by the imaginary imagos drawn down from the symbolic: "images of castration, emasculation, mutilation, dismemberment, dislocation, evisceration, devouring, and bursting open of the body." ${ }^{48}$ These are, as it were, the counter-imagos of the jubilant specular image: what happens, so to say, if the mask comes off. How are these horrors tied to mater?

"The phallus is the privileged signifier of this mark in which the role [part] of Logos is wedded to the advent of desire." ${ }^{49}$ The phallus consolidates our identity because it shapes how our need is returned to us as desire. Self and desire are a bewilderment of imagos-and never just the satisfaction of need-because a mother's love is promised to the phallus, the object that already commands her desire. That love is, at its most basic, the dialectic between presence and absence, which emerges as the "something other" left over after need is satisfied..$^{50}$ "This is what the primordial relationship with the mother manifests, replete as it is with that Other who must be situated shy of the needs that Other can fulfill." ${ }^{51}$ The mother is the veil of the phallus for her identity is a consequence of it. Every child's desire is rendered to it via a castrated circuit lodged in the mother. In other words, the child's desire is the gift of a mother whose desires, in their turn, are originally gifted by her mother-and so on:

I am saying that it is in order to be the phallus-that is, the signifier of the Other's desire-that a woman rejects an essential part of femininity, namely, all its attributes, in the masquerade. It is for what she is not that she expects to be desired as well as loved. But she finds the signifier of her own desire in the body of the person to whom her demand for love is addressed..$^{52}$

The love of the mother for the child-the transformation of need into desire, in fact-is "situated shy of the needs that Other can fulfil," for a mother's love is a veil over the phallus around which she herself is oriented.

The demand for love can only suffer from a desire whose signifier is foreign to it. If the mother's desire is for the phallus, the child wants to be the phallus

47. Lacan, "Signification of the Phallus," 582.

48. Lacan, "Aggressiveness in Psychoanalysis," 85.

49. Lacan, "Signification of the Phallus," 581.

50. Ibid., 579.

51. Ibid., $579 f$.

52. Ibid., 583. 
in order to satisfy her desire. Thus the division immanent in desire already makes itself felt by virtue of being experienced in the Other's desire. ${ }^{53}$

The immanent division-that is, the mother's own split identity between need, demand, and desire. The mutated need of the child, now the child's desire, is the signifier that is the child's identity, a product of a mother's divided love on account of her relationship to the phallus. This signifier, the root of the child's world, its projective geometry, issues from the masquerade of a mother's love, for her motherly love is in fact what is returned to the child after her own encounter with the phallus: "since this signifier is there only as veiled and as ratio [raison] of the Other's desire, it is the Other's desire as such that the subject is required to recognize." ${ }^{54}$ That the child's identity is a consequence of a relationship with another, other than the mother, is veiled, but very much present, in the mother's love for the child-veiled, that is, until mutating in castration. The child's identity is an echo of a regressive series of prior loves, punctuated by the prohibiting love of the castrating father (castration for Lacan is necessary, and therefore essentially positive).

Not exclusively, perhaps, ${ }^{55}$ but typically, the Other's desire-the phallus for the mother-is male sexuality. Human desire is "bound up since the dawn of history with the imago of the father." ${ }^{56}$ The father, argues Lacan, is the vehicle by which the narcissistic child "transcends himself in a normative sublimation." ${ }^{57}$ The father is the root of sympathy and moral order. "Oedipal identification" transfers narcissistic self-aggression onto the father, who, in turn, castrates, and dampens the child's jealous aggression at source. ${ }^{58}$ This dampening generates sympathy, which, in Lacan, is built on the recognition demanded by the father, an interdict ${ }^{59}$ present in a mother's love. This capture of what love a mother can give to a child is, observes Lacan, the reason for the law's forceful insistence on respect

53. Ibid., 582.

54. Ibid., $581 \mathrm{f}$.

55. In the 1958 essay “The Signification of the Phallus," Lacan's acceptance of sexual difference, and distinctive psychologies for men and women, is prominent.

56. Lacan, "Aggressiveness in Psychoanalysis," 95.

57. Ibid., 97.

58. Lacan, "Guiding Remarks," 613.

59. Jacques Lacan, "The Subversion of the Subject and the Dialectic of Desire in the Freudian Unconscious," in Écrits: The First Complete Edition in English, trans. Bruce Fink (New York, NY: W.W. Norton, 2006), 698; Lacan, "Signification of the Phallus," 582. 
for property. Property and establishment are a nod to the psychological authority of the father.

We propose that because robots are motherless, the desire structure of AI is sui generis different from humans. It is not on account of our intelligence that we have been promised the visio dei, nor because we are capable of conscious self-reflection-rather, in spite of it: on account of our bewildering desire and fraught projective geometry. Let us now complement Lacanianism with Thomism and demonstrate this last point.

\section{MARY, Mother OF GoD}

Lacan suggests that signifiers and signifieds relate by way of submission. He says that: "Conversely, it is Freud's discovery that gives the signifier/ signified its full scope: for the signifier plays an active role in determining the effects by which the signifiable appears to succumb to its mark, becoming, through that passion, the signified." ${ }^{0}$ Through that passion is submission to the phallus. How do the Passion and Mary, Mater Dei, relate?

Przywara is especially worried by the human tendency to pacify God, to think of God as something like an unproblematic close friend. He makes clear that there is no warrant for such an idea scripturally or philosophically and indeed, rather the reverse. Many biblical texts-and not only the Book of Job-speak of an uncanny God, a God who allots fate and leads souls into and out of the underworld; a God who seemingly loves one moment, and flies into a rage in another. ${ }^{61}$

Whenever Przywara speaks of God as uncanny he also speaks of God as behind a curtain or peering through a veil. ${ }^{62}$ The veil is composed of symbols. One of these is God manifest in the "babbling of a babe." The birth of Christ interrupts our conceptual clarity about God, we are stumped by

60. Lacan, "Signification of the Phallus," 578.

61. Erich Przywara, "Metaphysics, Religion, Analogy," in Analogia Entis: Metaphysics: Original Structure and Universal Rhythm, trans. John R. Betz and David Bentley Hart (Grand Rapids, MI: Wm. B. Eerdmans, 2014), 413f.; Erich Przywara, "Man, World, God, Symbol," in Analogia Entis: Metaphysics: Original Structure and Universal Rhythm, trans. John R. Betz and David Bentley Hart (Grand Rapids, MI: Wm. B. Eerdmans, 2014), 496; Erich Przywara, "Beautiful, Sacred, Christian," in Analogia Entis: Metaphysics: Original Structure and Universal Rhythm, trans. John R. Betz and David Bentley Hart (Grand Rapids, MI: Wm. B. Eerdmans, 2014), 547f.

62. See Erich Przywara, "Image, Likeness, Symbol, Mythos, Mysterium, Logos," in Analogia Entis: Metaphysics: Original Structure and Universal Rhythm, trans. John R. Betz and David Bentley Hart (Grand Rapids, MI: Wm. B. Eerdmans, 2014), 430-62; and Erich Przywara, "Imago Dei: On the Theological Message of Max Picard," in Analogia Entis: Metaphysics: Original Structure and Universal Rhythm, trans. John R. Betz and David Bentley Hart (Grand Rapids, MI: Wm. B. Eerdmans, 2014), 556-69. 
"the babbling of the Mysterium Mysteriorum." ${ }^{33}$ This symbol picks out the "in-and-beyond" structure of analogy. Every baby is in the natural order, but each also has the quality of a visitation, a coming from beyond, a mysterious popping into existence. ${ }^{64}$ God born of a woman is a radical intensification of something already difficult to fathom. As a metaphysical and epistemic structure, analogy forestalls a scientific grasp of God and pushes us into embodied practice-what Przywara calls a "posture of distance." ${ }^{65}$ Promulgated at the IV Lateran Council, the doctrine of analogy runs:

One cannot note any similarity between Creator and creature, however great, without being compelled to note an even greater dissimilarity between them. ${ }^{66}$

Przywara argues that Thomas Aquinas internalised the profound implications of the Council in a particular way. Thomistic theology became the great advocate of the Council, with Thomas deploying its rubric to assess questions and rival systems of thought. In light of Thomas, Przywara argues that Mary is a symbol of proximate distance: "the in-and-beyond of the 'symbol' is immediately transparent to the in-and-beyond of the Divine Mysterium Mysteriorum that resides in-and-beyond all divine manifestations and revelations, however great." ${ }^{67}$ Respecting the in, Mary, Mother of God, makes God intimate to us-birthing and mothering Jesus-and respecting the beyond, her "posture of distance"68-her humility-retains God's majesty, mystery, and sovereignty. Mary exemplifies the analogia entis to which she gives birth. Let us compare and contrast Mary as veil of God with Lacan's treatment of a mother's love as veil of the phallus.

Mary is a symbol of the uncanny God. She holds the analogical position; but what of the equivocal and univocal? Lacan is a good guide to the equivocal. The phallus is a signifier of lack, and a mother's love returns as the phallus to the child after her own encounter with the phallus: "since this

63. Przywara, "Man, World, God, Symbol," 500.

64. Lacan's understanding of desire is such that it "appear[s] ex nihilo, as if out of nothing," see Erin Felicia Labbie, Lacan's Medievalism (Minneapolis, MN: University of Minnesota Press, 2006), 11.

65. Erich Przywara, "The Scope of Analogy as a Fundamental Catholic Form," in Analogia Entis: Metaphysics: Original Structure and Universal Rhythm, trans. John R. Betz and David Bentley Hart (Grand Rapids, MI: Wm. B. Eerdmans, 2014), 375.

66. Heinrich Denzinger, quoted and translated in Przywara, Analogia Entis, 234 n. 232.

67. Przywara, "Man, World, God, Symbol," 500.

68. Also a "posture" of "service as distance," see Erich Przywara, "Philosophies of Essence and Existence," in Analogia Entis: Metaphysics: Original Structure and Universal Rhythm, trans. John R. Betz and David Bentley Hart (Grand Rapids, MI: Wm. B. Eerdmans, 2014), 347. 
signifier is there only as veiled and as ratio [raison] of the Other's desire, it is the Other's desire as such that the subject is required to recognize." ${ }^{69}$ The child's fragmentation is built upon a prior fragmentation of the mother, which, in turn, is built upon yet another prior fragmentation. ${ }^{70}$ This regress of desire is equivocity: a Heraclitean instability and partibility. It is what gives Lacanian desire its dialectic form ${ }^{71}$-but such an Heraclitean "contradictoriness"72 (here as lack and phallic fulfillment) is no stranger to Przywara's analogical form.

An assessment of the theology of the imago Dei cannot "be separated from a genuine theology of the sexes"73 and it is in this light that our psychology can be redeemed. In this theology, the equivocal position is bleak, Przywara speaking of the "transacted human being" exchanged as "goods at a slave market." ${ }^{2}$ This is the position of humiliation, where each of us is whatever is demanded of us. The world as a "consortium anti-Dei"75 is a world with sexual relations disfigured, ruptured, and twisted in commercial civilization. Przywara grants Lacan's dark assessment of family structured by the phallus, imagos of the symbolic. Here, child and mother submit to the sovereign power of male desire, the phenomenology of which has been ably surveyed by St. John Paul II. ${ }^{76}$ Male desire, the phallus, holds the univocal position. It is sovereign, with a Parmenidian stability and impenetrability. ${ }^{77}$

Mary is mother in the analogical position, suspending the pull of the Heraclitean axis and the Parmenidian axis. Mary is analogical in two ways, metaphysically and as veil. Metaphysically, she is the "nuptial womb."78 Giving birth, she is emblematic of "the vegetal-animal form of "male and

69. Lacan, "Signification of the Phallus," $581 f$.

70. For an interesting overview of the changing role of the mother in Lacanian theory, see the "Introduction: From 'Maternal Presence' to 'Maternal Object,"' in Shuli Barzilai, Lacan and the Matter of Origins (Stanford, CA: Stanford University Press, 1999), 1-7.

71. See Lacan, "The Subversion of the Subject and the Dialectic of Desire in the Freudian Unconscious."

72. Erich Przywara, "Phenomenology, Realogy, Relationology," in Analogia Entis: Metaphysics: Original Structure and Universal Rhythm, trans. John R. Betz and David Bentley Hart (Grand Rapids, MI: Wm. B. Eerdmans, 2014), 472f.

73. Przywara, “Imago Dei: On the Theological Message of Max Picard” 563.

74. Ibid., 567.

75. Ibid., 566.

76. Pope St. John Paul II, “Mulieris Dignitatem: On the Dignity and Vocation of Women," Apostolic Letter, 15 August 1998, https://w2.vatican.va/content/john-paul-ii/en/apost_letters/1988/documents/hf_jp-ii_apl_19880815_mulieris-dignitatem.html.

77. See Przywara, Analogia Entis, 205-7.

78. Przywara, “Imago Dei: On the Theological Message of Max Picard” 569. 
female"'79 (equivocity), but, giving birth to Christ, she is mother of the phallus redeemed, the new Adam (univocity). She is "an almost antithetical supernatural form" 80 : antithetical to the sexual politics of the consortium anti-Dei (equivocity), but otherwise a symbol of grace perfecting nature (univocity). In this light, she is mother at the origin of creation:

If, from the perspective of the original form, the external visible world stands under the form of the "man as head," in its invisible interior it bears the supernatural form of "Mary as the womb and inner form" of all redeemed life. ${ }^{81}$

The relationship between men and women is reversed, the phallus sidelined: male desire "now appears as a veil 'veiling' the mystery of Mary as the 'nuptial womb' $(\theta \dot{\alpha} \lambda \alpha \mu \mathrm{\alpha})$ of all redeemed life."82

This is nature (equivocity) perfected by grace (univocity), and yet, it is still an incomplete accounting. The full accounting is present in Mary as veil, as Mater Dei, symbol of the uncanny God.

With Mary as symbol, the phallus is reasserted, but sexual politics transformed. The uncanny Father sends the Son to take the form of a slave, to be supine (equivocity) before sovereign man-Imperial Rome (univocity). But Christ and Mary (through her participation in Christ as analogia entis) suspend both these positions: "The imago Dei, in the full sense of this term, is the human being in the symbol of the 'crucified' and the 'mother of seven sorrows." ${ }^{83}$ This suspension happens in Christ's sacrifice; the new phallus no longer the dominium of male desire, but the Cross as a symbol of a new cooperation of man and woman in service to the child: "The Christ in whom this 'newness' occurs is fully concrete as Christ, the second Adam, and Mary, the second Eve." ${ }^{84}$ The humiliation of the Cross (equivocity) in Mary is transformed by humility into a high-minded serenity (univocity), unto "a sword will pierce your own heart"; a humility which is an obedience to ${ }^{85}$ (analogy) an uncanny sacrificing Father (mystery of the perfect phallus):

79. Ibid., 561.

80. Ibid., 569 .

81. Ibid.

82. Ibid.

83. Ibid.

84. Ibid., 568.

85. Obedience which is analogically in accord with the sense of the "potentia oboedientialis" which is "open upwards" to God, see both Erich Przywara, Polarity. A German Catholic's Interpretation of Religion, trans. Alan Coates Bouquet (London: Oxford University Press, 1935), 29; and Przywara, Analogia Entis, 227. 
"For the 'imago Dei' in the 'second Adam, Christ' and in the 'second Eve, Mary' has the form of a 'consortium naturae divinae." 86

AI will be more prosaic than technologists think because AI cannot participate in the "the drama of primordial jealousy" that characterises human life. This world, this enchantment, is fraught, for its "symbolic matrix" is the masquerade of a mother's love. A mother's love is a mask behind which is the phallus that limits and transmutes a child's needs. The child's desire is what the child is allowed, for the phallus is a jealous god. Mater is an unreliable witness to familial love and this is why Przywara says that Mary redeems our dereliction: she births the One who castrates (in the Lacanian sense) all male desire, the desire of the slave market.

Male desire as sacrificial love-a theological castration of the Lacanian phallus-is a difficult teaching, and for this reason a veil is necessary. Christ is the plenitude of power made powerless; a curse made a blessing; shame made glory. Mary is the symbol that makes the Cross human: who shows through her sorrows the Deus humanatus. Veil of the Cross, her humility conveys the "posture of distance" that submits to the authority of the mystery of God. Mary is the mother's love submitted-an ecstatic fiat-to the mystery of the perfect phallus. The phallus now made "plain" in the symbol of babbling babe-the babe woven into the meaning of the symbol of the Cross.

\section{CONCLUSION}

Our argument has been that $\mathrm{AI}$ as cognitive perfection is no challenge to Christianity as that perfection skews wide of the real centre of Christian reflection: the family. The family, because persons, in their psychological and intellectual development, mature inside family. AI is birthed inside structures of accounting and engineering; humans inside a family drama keyed to potent structures of sexuality. The visio dei made possible through the Cross is offered to persons on account of their origins in families. Christianity does not address abstract cognition, but cognitive powers maturing in a framework of the imaginary and symbolic. If anything, the coming robot revolution will bring to fresh clarity the significance of family and Christian personalism.

However, we close with a caveat. Already back in 1948, Lacan considered the "technological enterprise" of humanity to be a final working out of the (Hegelian) Master-Slave dialectic. ${ }^{87}$ The question is whether human beings are to end up subservient to the machine through an individualising 
tendency, which Lacan sees in the "utilitarian conception of man" that coexists with a world bent on "the promotion of the ego." 88 Such a future world of technoscientific subservience is premised on such a promotion, in that the egological utilitarianism procures a "psychotechnics" in which human life is mechanised or robotised. There is here no straightforward divinising of humanity's creative capacity, where robots are produced in our image and likeness. Rather, the reverse: humans recast in the image of robots. Given that, for Lacan, our real sense of subjectivity is in fact obscured from conscious view, no act of creation on our part will occur without a concomitant backlash: creation of machines necessarily involves the simultaneous refashioning of the human self-image. In other words, when we create, we change things that we never (consciously) intendedand far from being merely unforeseen consequences, they are consequences which are occurring at a non-conscious (and thus undiscoverable) level. ${ }^{89}$ We can, however, see their effects.

One of those effects is the changing image of the human person. This means that the rise of the machine coincides with an equal and opposite rise of psychotechnic man: the commodification of affectivity, allowing for its manipulation and use according to utilitarian ends. In this way, the image of man and the image of the machine coincide in a mutual creation. The utopian ideal of technology as the "simulacrum of the living," thus allowing it to be subordinated to human use, is for Lacan a fantasy. As such, the machine "embodies the most radical symbolic activity of man," and introduces, for the first time, "energy" as a subject of consideration ${ }^{90}$-"energy" in the industrial scene led, as it were, to the conception of human energies (in ways which Lacan attempts to correct). The question thus ceases to be "can AI become like human beings?" and is shown instead to be "what is the human being, once AI is created?"

In other words, Lacan also does not think cognitive perfection or a machine coming to self-awareness is the real challenge. In accord with his way of thinking, the threat to humanism and Christian personalism comes from humans conceding they are just machines. To our theme, machine wombs could strengthen considerably the consortium anti-Dei. Ostensibly, and

88. Ibid.

89. A similar point is made about Lacan and AI with respect to Lacan's understanding of the "Real" (in short: that which cannot be represented in language) in Bert Olivier, "Body, Thought, Being-Human and Artificial Intelligence: Merleau-Ponty and Lyotard," South African fournal of Philosophy 21, no. 1 (January 2002): 56, https://doi.org/10.4314/sajpem.v21i1.31335.

90. Lacan, The Seminar of Jacques Lacan. Book 2: The Ego in Freud's Theory and in the Technique of Psychoanalysis 1954-1955, 74-5. 
very positively, they are being designed to house the prematurely born. ${ }^{91}$ At one level, they change nothing about the need, demand, and desire of the infant. Our thesis can sail smoothly on. At another level, however, they surely will affect motherhood. They will reaffirm the unredeemed phallus. Pope Francis warns of the "technocratic paradigm:"92 the imperial grip of technoscience a case of univocity, further encouraging ideals of the "transacted human being." Artificial wombs are economic objects, monitored by accountants and engineers. Our analysis is not invalidated, but seeing the light of Stella Maris will become harder, the veil will thicken.

\section{BIBLIOGRAPHY}

Barzilai, Shuli. Lacan and the Matter of Origins. Stanford, CA: Stanford University Press, 1999. Borunda, Alejandra. "The Internet Is Drowning." Science \& Innovation, 16 July 2018. https://www. nationalgeographic.com/science/2018/07/news-internet-underwater-sea-level-rise/.

Bossenga, Gail. The Politics of Privilege: Old Regime and Revolution in Lille. Cambridge: Cambridge University Press, 2002.

DeMuro, Rich. "Walmart Robots Working Store Aisles, Checking Stock-YouTube." Accessed August 3, 2019. https://www.youtube.com/watch?v=KRJV1SPYpIE.

Francis, Pope. "'Laudato Si': On Care for Our Common Home." Encyclical Letter, 24 May 2015. https://w2.vatican.va/content/francesco/en/encyclicals/documents/papa-francesco_20150524_enciclica-laudato-si.html.

Garland, Alex. Ex Machina, 2014.

Harari, Yuval. Homo Deus: A Brief History of Tomorrow. London: Vintage, 2017.

John Paul II, Pope St. "Mulieris Dignitatem: On the Dignity and Vocation of Women." Apostolic Letter, 15 August 1998. https://w2.vatican.va/content/john-paul-ii/en/apost_letters/1988/ documents/hf_jp-ii_apl_19880815_mulieris-dignitatem.html.

Josephson-Storm, Jason A. The Myth of Disenchantment: Magic, Modernity, and the Birth of the Human Sciences. Chicago, IL and London: University of Chicago Press, 2017.

Keating, Jessica. "Artificial Wombs and the Intellectual Tasks of Building Cultures of Life." Church Life Journal, 5 September 2017. https://churchlifejournal.nd.edu/articles/ artificial-wombs-and-the-intellectual-tasks-of-building-cultures-of-life/.

Kessler, Andy. "Will Bitcoin Save Us From Google?" Accessed July 16, 2018. https://www. andykessler.com/andy_kessler/2018/07/wsj-.html.

Labbie, Erin Felicia. Lacan's Medievalism. Minneapolis, MN: University of Minnesota Press, 2006.

Lacan, Jacques. "Aggressiveness in Psychoanalysis." In Écrits: The First Complete Edition in English. Translated by Bruce Fink, 82-101. New York, NY: W.W. Norton, 2006.

91. Jessica Keating, "Artificial Wombs and the Intellectual Tasks of Building Cultures of Life," Church Life fournal, 5 September 2017, https://churchlifejournal.nd.edu/articles/ artificial-wombs-and-the-intellectual-tasks-of-building-cultures-of-life/.

92. Pope Francis, “Laudato Si': On Care for Our Common Home," Encyclical Letter, 24 May 2015, https://w2.vatican.va/content/francesco/en/encyclicals/documents/papa-francesco_20150524_enciclica-laudato-si.html. 
— . "Guiding Remarks for a Convention on Female Sexuality." In Écrits: The First Complete Edition in English. Translated by Bruce Fink, 610-620. New York NY: W.W. Norton, 2006.

- . "In Memory of Ernest Jones: On His Theory of Symbolism." In Écrits: The First Complete Edition in English. Translated by Bruce Fink, 585-601. New York, NY: W.W. Norton, 2006.

- . "The Mirror Stage as Formative of the IFunction as Revealed in Psychoanalytic Experience." In Écrits: The First Complete Edition in English. Translated by Bruce Fink, 75-81. New York, NY: W.W. Norton, 2006.

- . "On a Question Prior to Any Possible Treatment of Psychosis." In Écrits: The First Complete Edition in English, 445-488. New York, NY: W.W. Norton, 2006.

- . "Position of the Unconscious." In Écrits: The First Complete Edition in English. Translated by Bruce Fink, 703-721. New York, NY: W.W. Norton, 1948.

—. "Remarks on Daniel Lagache's Presentation: 'Psychoanalysis and Personality Structure." In Écrits: The First Complete Edition in English. Translated by Bruce Fink, 543-574. New York, NY: W.W. Norton, 2006.

- . "Seminar on 'The Purloined Letter." In Écrits: The First Complete Edition in English. Translated by Bruce Fink, 6-48. New York NY: W.W. Norton, 2006.

- The Seminar of Jacques Lacan. Book 2: The Ego in Freud's Theory and in the Technique of Psychoanalysis 1954-1955. Edited by Jacques-Alain Miller. Translated by Sylvana Tomaselli. Cambridge: Cambridge University Press, 1988.

- . "The Signification of the Phallus." In Écrits: The First Complete Edition in English. Translated by Bruce Fink, 575-584. New York, NY: W.W. Norton, 1948.

- . "The Subversion of the Subject and the Dialectic of Desire in the Freudian Unconscious." In Écrits: The First Complete Edition in English. Translated by Bruce Fink, 671-702. New York, NY: W.W. Norton, 2006.

Lubac, Henri de. The Drama of Atheist Humanism. Translated by Edith M. Riley, Anne Englund Nash, and Mark Sebanc. San Francisco, CA: Ignatius Press, 1995.

McAleer, Graham J. “All Valid Law Is Analogical." Law \& Liberty, 16 November 2015. https:// www.lawliberty.org/book-review/all-valid-law-is-analogical/.

- Ecstatic Morality and Sexual Politics: A Catholic and Antitotalitarian Theory of the Body. Moral Philosophy and Moral Theology Series 5. New York, NY: Fordham University Press, 2005.

- Erich Przywara and Post-Modern Natural Law. Notre Dame, IN: University of Notre Dame Press, 2019.

— . “Jacques Lacan: Conservative Icon?" Law \& Liberty, 17 January 2018. https://www. lawliberty.org/2018/01/17/jacques-lacan-conservative-icon/.

Mims, Christopher. "Career of the Future: Robot Psychologist." Wall Street fournal, 9 July 2017, sec. Tech. https://www.wsj.com/articles/career-of-the-future-robot-psychologist $-1499605203$.

Olivier, Bert. "Body, Thought, Being-Human and Artificial Intelligence: Merleau-Ponty and Lyotard." South African fournal of Philosophy 21, no. 1 (January 2002): 44-62. doi:10.4314/ sajpem.v21i1.31335.

Parliament, House of Lords. "Make or Break-The UK's Digital Future." Report of Session 2014-15. London: Select Committee on Digital Skills, 2015. https://publications.parliament.uk/pa/ld201415/ldselect/lddigital/111/111.pdf.

Przywara, Erich. Analogia Entis: Metaphysics: Original Structure and Universal Rhythm. Translated by John R. Betz and David Bentley Hart. Grand Rapids, MI: Wm. B. Eerdmans, 2014. 
- . "Beautiful, Sacred, Christian." In Analogia Entis: Metaphysics: Original Structure and Universal Rhythm. Translated by John R. Betz and David Bentley Hart, 537-555. Grand Rapids, MI: Wm. B. Eerdmans, 2014.

— . "Image, Likeness, Symbol, Mythos, Mysterium, Logos." In Analogia Entis: Metaphysics: Original Structure and Universal Rhythm. Translated by John R. Betz and David Bentley Hart, 430-462. Grand Rapids, MI: Wm. B. Eerdmans, 2014.

- .Imago Dei: On the Theological Message of Max Picard." In Analogia Entis: Metaphysics: Original Structure and Universal Rhythm. Translated by John R. Betz and David Bentley Hart, 556-569. Grand Rapids, MI: Wm. B. Eerdmans, 2014.

- . "Man, World, God, Symbol." In Analogia Entis: Metaphysics: Original Structure and Universal Rhythm. Translated by John R. Betz and David Bentley Hart, 480-500. Grand Rapids, MI: Wm. B. Eerdmans, 2014.

— . "Metaphysics, Religion, Analogy." In Analogia Entis: Metaphysics: Original Structure and Universal Rhythm. Translated by John R. Betz and David Bentley Hart, 409-429. Grand Rapids, MI: Wm. B. Eerdmans, 2014.

- . "Phenomenology, Realogy, Relationology." In Analogia Entis: Metaphysics: Original Structure and Universal Rhythm. Translated by John R. Betz and David Bentley Hart, 463-479. Grand Rapids, MI: Wm. B. Eerdmans, 2014.

- . "Philosophies of Essence and Existence." In Analogia Entis: Metaphysics: Original Structure and Universal Rhythm. Translated by John R. Betz and David Bentley Hart, 317-347. Grand Rapids, MI: Wm. B. Eerdmans, 2014.

- . Polarity. A German Catholic's Interpretation of Religion. Translated by Alan Coates Bouquet. London: Oxford University Press, 1935.

- . "The Scope of Analogy as a Fundamental Catholic Form." In Analogia Entis: Metaphysics: Original Structure and Universal Rhythm. Translated by John R. Betz and David Bentley Hart, 348-399. Grand Rapids, MI: Wm. B. Eerdmans, 2014.

Riou, Jeanne, and Mary Gallagher, eds. Re-Thinking Ressentiment: On the Limits of Criticism and the Limits of Its Critics. Cultural and Media Studies. Berlin: De Gruyter, 2016.

Savage-Rumbaugh, Sue, and Roger Lewin. Kanzi: The Ape at the Brink of the Human Mind. New York, NY: John Wiley \& Sons, 1994.

Scheler, Max. Ressentiment. Translated by Lewis B. Coser and William W. Holdheim. New Ed. Marquette Studies in Philosophy 4. Milwaukee, WI: Marquette University Press, 1994. 